\title{
Kedudukan Workstation Canting pada Tata Ruang Workshop Batik Tulis Oey Soe Tjoen
}

\author{
Rachmi Kumala Widyasari, Agus Sachari, Andar Bagus Sriwarno, G. Prasetyo Adhitama \\ Program Studi Doktor Ilmu Seni Rupa dan Desain, Fakultas Seni Rupa dan Desain \\ Institut Teknologi Bandung \\ Jl. Ganesha No. 10, Bandung 40132 \\ rkwidyasari@students.itb.ac.id, mila.djoko@gmail.com
}

\begin{abstract}
The Oey Soe Tjoen batik workshop is one of the Nusantara's traditional batik tulis workshops that maintains originality in producing batik for generations. The process of producing batik with canting plays an essential role in the Oey Soe Tjoen batik workshop. The purpose of this study was to review the position of the process in producing batik with canting in the traditional batik tulis workshop, within the scope of the working process and in the spatial order. This research used an ethnographic approach through literature studies, observations, and direct interviews. The data are presented descriptively and analyzed to produce findings that the process of producing batik with canting is essential in producing traditional batik tulis so that the space that accommodates this process becomes an essential space in the layout of a traditional batik tulis workshop that needs to consider in order to support productivity.
\end{abstract}

Keywords: Batik Tulis, Canting, Hierarchy, Oey Soe Tjoen, Workstation

\begin{abstract}
ABSTRAK
Rumah batik Oey Soe Tjoen adalah salah satu workshop batik tulis tradisional Nusantara yang mempertahankan orisinalitas dalam menghasilkan kain batik secara turun temurun. Proses produksi kain batik dengan canting memegang peranan penting dalam rumah batik Oey Soe Tjoen. Tujuan penelitian ini adalah untuk meninjau kedudukan proses pembuatan kain batik dengan canting pada usaha batik tulis tradisional, baik dalam lingkup proses kerja maupun dalam lingkup tatanan ruang. Penelitian ini menggunakan pendekatan etnografi melalui studi literatur, observasi, dan wawancara langsung kepada narasumber. Data dipaparkan secara deskriptif dan dianalisis sehingga menghasilkan temuan bahwa, proses produksi kain batik dengan canting adalah sebuah proses yang signifikan dalam menghasilkan batik tulis secara tradisional. Sehingga ruang yang mewadahi proses ini menjadi ruang penting dalam tata ruang sebuah workshop batik tulis tradisional yang perlu dipertimbangkan perancangannya guna mendukung kelancaran produktivitas kerja.
\end{abstract}

Kata Kunci: Batik Tulis, Canting, Hirarki, Oey Soe Tjoen, Workstation

\section{PENDAHULUAN}

Batik sebagai salah satu warisan budaya nonbenda dunia yang berasal dari Indonesia memiliki sejarah yang panjang dalam perkembangan budaya Nusantara. Tidak dapat dipungkiri, akulturasi antara budaya lokal dengan budaya asing juga tampak dalam produk kebudayaan, salah satunya adalah kain batik. Pada daerah pesisir utara Jawa yang terkenal sebagai melting pot, akulturasi budaya asing dan lokal menghasilkan kain batik yang khas bernama Batik Peranakan. 


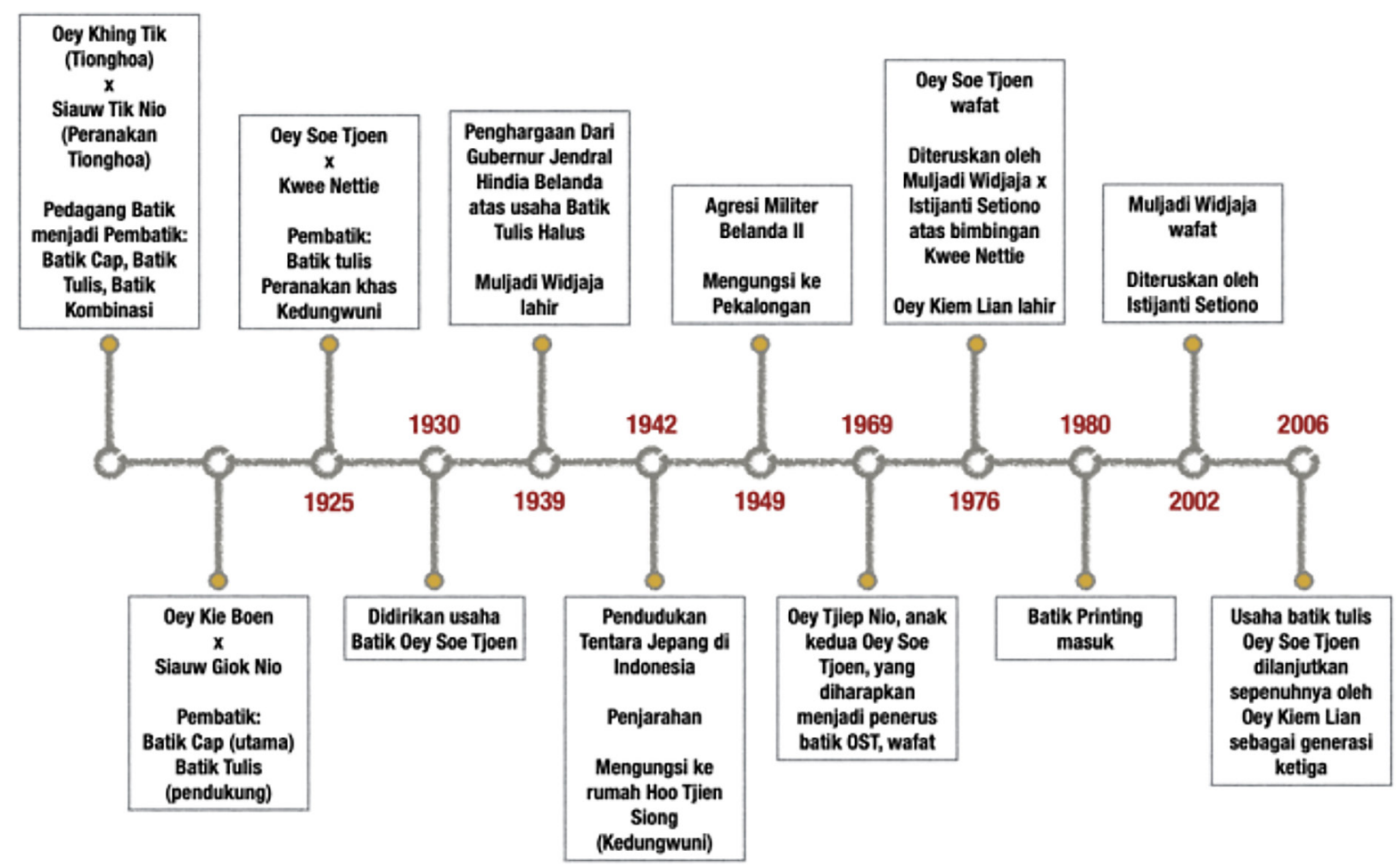

Gambar 1. Lini masa perkembangan batik Oey Soe Tjoen (Sumber: Widyasari, 2019)

Pada saat itu, wanita Peranakan Tionghoa Jawa atau yang lebih dikenal dengan kaum Nyonya lebih sering menggunakan kebaya dengan sarung Panjang atau kain Panjang yang terbuat dari kain batik (Kwa, hlm. 2018). Kain batik yang mereka gunakan bermotif ragam hias Eropa yang dipadukan dengan ragam hias Tionghoa. Kain batik tersebut memiliki warna-warna ceria khas Tionghoa yang merupakan hasil dari pewarna sintetis.

Beberapa pembatik pekalongan yang terkenal dengan hasil karya batik halusnya adalah The Tie Siet, Oey Soen King, Oey Kok Sing, Liem Giok Kwie, Liem Siok Hien, Lim Boe In, Lim Boen Gan serta Oey Soe Tjoen dari Kedungwuni (Kwa, 2018). Bahkan hasil karya mereka terkenal hingga ke Singapura, Malaka, dan Penang.
Sejarah dan Perkembangan Batik Oey Soe Tjoen

Kedungwuni adalah sebuah kecamatan yang terletak sebelas kilo ke arah selatan Kabupaten Pekalongan, Provinsi Jawa Tengah. Sejak dahulu, daerah Kedungwuni terkenal dengan batik Peranakannya yang khas, hasil karya para pembatik keturanan Tionghoa Jawa. Batik Peranakan Kedungwuni memiliki ciri khas motif buketan dan warna-warna pastel serta isen-isen yang detail. Rumah batik Oey Soe Tjoen adalah salah satu rumah batik yang masih memproduksi batik Peranakan Kedungwuni hingga kini. Batik Oey Soe Tjoen terkenal dengan usahanya dalam melestarikan baik motif maupun proses pembuatan batik tradisional secara turun temurun. Batik ini memiliki ciri khas berupa motif kupu-kupu serta gradasi warna khas yang membentuk efek kedalaman. Beberapa ciri khas desain 
batik Oey Soe Tjoen (Liong,hlm. 2014) adalah yang pertama batik ini menggunakan kain katun primisima terbaik yang melalui proses pengethelan terlebih dahulu dan juga teknik pembuatannya yang dilakukan dengan teknik batik tulis sepenuhnya, dengan proses pembatikan yang sama pada kedua sisinya. Hanya terdapat empat jenis motif utama dari batik Oey Soe Tjoen yaitu Buketan, Cuwiri, Merak Ati, dan Urang Ayu. Selain daripada motif, terdapat pula jenis ragam isen-isen yang khas serta teknik jaretan dalam proses pembuatan batik yang menghasilkan gradasi warna. Ciri khas desain yang terakhir dan yang paling adalah, terdapat tanda tangan Oey Soe Tjoen di setiap kain yang dihasilkan dari generasi pertama hingga kini.

Seperti pada gambar 1 yang merupakan sejarah singkat perkembangan batik Oey Soe Tjoen dari awal hingga saat ini.

Proses produksi Batik Oey Soe Tjoen sepenuhnya menggunakan teknik canting dengan pewarnaan celup. Secara umum peralatan yang digunakan dalam proses produksi batik ini, sama dengan batik tulis tradisional yang lain. Proses batik tulis menggunakan peralatan seperti gawangan, canting, tungku, dan malam panas(Hasanudin, 2001), sedangkan untuk proses pewarnaan batik Oey Soe Tjoen menggunakan alat celup tradisional dan alat celup yang dimodifikasi atas pertimbangan kenyamanan postural (Widyasari, Sachari, Sriwarno, \& Adhitama, 2020).

Beberapa tahapan dalam memproduksi batik Oey Soe Tjoen (Liong, hlm. 2014) adalah sebagai berikut.
Tahap Pertama diawali dengan membuat pola atau motif batik di atas kertas dengan menggunakan pensil. Pembuatan pola atau motif berdasarkan kerativitas juru gambar dalam hal ini ibu Widianti Widjaja sebagai generasi ketiga dari batik Oey Soe Tjoen. Namun demikian, proses ini juga dapat dipengaruhi oleh keinginan klien. Setelah itu, kain memasuki tahap proses canting yang disebut klowongan. Klowongan yaitu penggambaran garis outline pada motif dengan menggunakan canting dan malam panas. Proses klowongan dilanjutkan dengan tahap Ngiseni, yaitu pemberian isian atau detail ke dalam bidang gambar yang sudah diberi outline dengan menggunakan canting dan malam panas. Setelah proses ini selesai, kemudian dilanjutkan dengan proses Mopok yaitu menutup bagian-bagian tertentu berwarna putih (warna dasar kain) pada kain batik yang direncanakan untuk tidak diberi warna menggunakan malam sebagai perintang warna. Setelah itu, kain akan melalui tahap Nerusi yaitu melakukan proses pembatikan pada sisi kain yang lain secara tepat, baik Klowongan ataupun Isen-isennya. Setelah itu, baru kemudian kain masuk ke tahap pewarnaan atau Ngelir. Dalam proses pewarnaan terdapat sebuah proses yang amat penting, yaitu proses Njareti atau penutupan sebagian motif dengan bentuk khusus agar dapat menghasilkan gradasi warna tiga dimensi pada motif, yang kemudian menjadi ciri khas dari batik Oey Soe Tjoen.

Proses ini berulang dari proses Mopok hingga Ngelir lalu Nglorod yaitu pencucian kain dengan air panas untuk peluruhan 
malam, cuci, jemur, tarik, dan kemplong hingga kain yang dihasilkan sesuai dengan desain yang diinginkan. Secara rinci proses ini akan dibahas pada bagian hasil dan pembahasan.

Sejarah dan Perkembangan Bangunan Rumah Batik Oey Soe Tjoen

Rumah batik Oey Soe Tjoen terletak di Kecamatan Kedungwuni yang dahulu terkenal dengan sebagai Kawasan Pecinan, di mana keluarga Oey adalah salah satu keluarga pembatik yang terkenal. Awal mulanya keluarga Oey hanya mengumpulkan kain-kain batik yang dihasilkan oleh masyarakat sekitar Kedungwuni untuk kemudian dijual kembali. Seiring dengan waktu, keluarga besar Oey memulai usaha batik sendiri, dimulai dengan usaha batik cap. Dengan majunya usaha batik keluarga Oey, Oey Soe Tjoen muda akhirnya bertekad untuk membuka usaha batiknya sendiri. Ia beserta istrinya membuka usaha batik tulis halus dengan motif buketan yang terinspirasi dari batik Belanda, Van Zulyen. Motif buketan Oey Soe Tjoen ini kemudian yang membawa batik Oey Soe Tjoen terkenal sebagai Duta Batik Peranakan.

Usaha batik tulis halus Oey Soe Tjoen ini kemudian membuatnya harus memiliki rumah usaha pribadi untuk memaksimalkan proses produksi. Pada awalnya, keluarga besar Oey memiliki empat buah rumah tipikal yang terletak di pinggir jalan raya Kedungwuni. Keempat rumah tersebut hingga kini masih dapat dijumpai dengan kepemilikan yang sudah berpindah. Salah satu rumah peninggalan keluarga Oey, dihuni oleh pembatik Lim Ping Wie. Rumah dengan tipe Rumah Besar atau Rumah Keluarga ini memiliki ciri hunian sekaligus ruang usaha yang biasa dijumpai pada Kawasan Pecinan di Indonesia.

Rumah Besar atau Rumah Keluarga memiliki ciri yang kuat dengan adanya meja sembahyang atau altar yang terletak setelah pintu masuk utama (Antariksa, hlm. 2016). Selain terdapatnya altar, rumah ini juga memiliki pembagian zoning yang cukup jelas, bentuk yang simetri dan hirarki ruang yang kuat serta terdapat lorong sebagai sirkulasi dan adanya halaman (courtyard) sebagai penghubung antar pembagian rumah.

Rumah Oey Soe Tjoen terletak tidak jauh dari rumah keluarga besar Oey, hanya terpisah beberapa meter ke selatan. Terlihat perbedaan bentuk dan fungsi bangunan dari bangunan rumah keluarga besar Oey dengan rumah Oey Soe Tjoen. Bangunan rumah Oey Soe Tjoen memiliki tampak depan yang hampir sama dengan rumah kampung pada umumnya. Hanya saja, bagian depan dari rumah ini juga berfungsi sebagai toko kelontong. Seperti layaknya rumah toko pada daerah Pecinan yang sering kita jumpai, bangunan rumah memiliki mutifungsi sebagai hunian sekaligus ruang usaha (Antariksa, hlm. 2016).

Penggunaan bentuk-bentuk geometris pada bangunan secara simbolis yang ditata berdasarkan arah mata angin, sangat dipengaruhi oleh budaya Tionghoa(Antariksa, 2016). Bentuk bujur sangkar, persegi panjang dan kubus misalnya, melambangkan duniabumi. Sedangkan bentuk-bentuk bulat melambangkan semesta-langit. Oleh sebab itu, pengunaan sistem grid sering digunakan 
pada layout rumah, dengan orientasi arah utara-selatan. Penentuan arah orientasi ini kemungkinan juga berkaitan dengan klimatologis, yaitu arah angin dan garis edar matahari.

Jenis material yang biasa digunakan dalam bangunan arsitektur Tionghoa, seperti yang dikutip dari Antariksa (2016) bahwa "Arsitektur Tionghoa dibangun tidak dengan bahan-bahan permanen, mungkin ada hubungannya dengan negasi terhadap segala bentuk yang bersifat fana. Susunan geometris, ritual-ritual, dan nilai hadir lebih utama dari bangunan yang dianggap fana."

Beberapa penelitian sebelumnya menjadi acuan dalam penelitian ini. Penelitian yang dilakukan melalui pendekatan historis dan obeservasi karakteristik ruang yang menungkapkan bahwa pada hunian rumah adat Kampung Pulo dapat diadaptasi menjadi konsep hunian masa kini (Sriwardani \& Savitri, 2019). Hal ini dikarenakan adanya aturan, larangan dan konsep rumah adat Kampung Pulo yang menciptakan tata ruang yang harmoni, proposional, dan berinteraksi baik dengan alam. Penelitian lainnya adalah penelitian yang menggunakan pendekatan historikal terhadap perkembangan ruang hunian dan ruang usaha batik. Penelitian ini mengungkapkan bahwa perubahan yang terjadi pada hunian sekaligus ruang usaha batik di Laweyan Solo terbagi atas dua, yaitu yang pertama adanya penambahan fungsi toko dan yang kedua adanya penambahan fungsi toko sekaligus ruang produksi batiknya. Perbedaan yang signifikan terlihat pada sirkulasi ruang, karena dengan adanya toko dan ruang produksi batik maka akses konsumen toko menjadi tidak berbatas dan menyatu dengan akses penghuni rumah (Hastuti, hlm. 2017).

Sehingga dari beberapa bahasan mengenai sejarah perkembangan usaha batik berikut dengan sejarah dan fungsi bangunannya, maka penelitian ini memiliki tujuan melihat lebih dalam hubungan yang terjadi antara proses produksi batik tulis Peranakan Oey Soe Tjoen dengan kedudukan ruang usaha batik dalam layout keseluruhan bangunan

\section{METODE}

Penelitian ini menggunakan pendekatan etnografi desain melalui observasi, wawancara, dan studi literatur. Etnografi desain digunakan untuk mengamati perilaku pengguna ruang, baik penghuni rumah maupun para pekerja dalam suatu kurun waktu. Pengumpulan data awal dilakukan melalui studi literatur, khususnya mengenai sejarah dan perkembangan budaya peranakan di daerah pesisir utara Jawa dan perkembangan batik Oey Soe Tjoen. Observasi dilakukan di lapangan secara langsung yang diawali dari lingkup mikro yaitu bangunan rumah batik Oey Soe Tjoen, kaitannya dengan rumah keluarga Oey yang terletak di Kawasan Pecinan Lama Kedungwuni. Observasi terhadap ruang arsitektural dan interior dilakukan untuk memahami fungsi ruang, khususnya yang berkaitan dengan proses pembuatan batik tulis secara tradisional. Wawancara dilakukan kepada pemilik usaha 
batik Oey Soe Tjoen generasi ketiga, Widyanti Widjaja. Wawancara ini dilakukan untuk menggali data tentang sejarah, tata cara kerja, dan proses batik dari tahap desain hingga tahap akhir. Selain pemilik usaha, wawancara juga dilakukan kepada para pekerja yang terlibat dalam setiap proses produksi dari proses membuat batik dengan canting, proses cuci, proses lorod, proses celup hingga proses pengeringan. Pengambilan data di lapangan ini dilakukan dalam secara bertahap dalam kurun waktu selama kurang lebih dua tahun.

Data-data penelitian lapangan kemudian diolah dan dianalisis secarabertahap pula. Diawali dengan pembahasan mengenai sejarah dan perkembangan usaha batik tulis Oey Soe Tjoen, bagaimana penyesuaian yang terjadi antara perilaku pengguna ruang dengan ruang-ruang pada bangunan dengan tiga fungsi ini. Analisis dilanjutkan dengan pembahasan khusus kepada ruang workshop batik tulis yang terletak di area belakang bangunan, termasuk di dalamnya analisis pencapaian dan sirkulasi. Pembahasan yang terakhir adalah pembahasan mengenai hubungan antara ruang workstation canting dengan pengguna ruang. Sehingga pada akhirnya terdapat kesimpulan berdasarkan hubungan antara pengguna ruang, proses kerja serta ruang-ruang yang digunakan.

\section{HASIL DAN PEMBAHASAN}

Hasil dan pembahasan dalam penelitian ini secara garis besar akan dibagi dalam beberapa bagian, yaitu sejarah dan budaya kerja batik Oey Soe Tjoen serta bahasan mengenai ruang-ruang yang terdapat dalam bangunan ini khususnya yang digunakan dalam proses membatik.

\section{Sejarah dan Budaya Kerja Batik Oey Soe Tjoen}

Rumah batik yang berdiri sejak tahun 1925 ini, dikelola oleh Widianti Widjaja sebagai generasi ketiga. Batik yang memiliki ciri motif khas Peranakan Kedungwuni berupa buketan bunga dengan teknik isen yang membentuk efek tiga dimensi ini, pada awalnya dipengaruhi oleh batik Belanda Van Zulyen. Kini seiring dengan perkembangan zaman, Widianti mencoba mengembangkan motif-motif kontemporer namun tetap mempertahankan motif Buketan sebagai motif pakem dari batik Oey Soe Tjoen.

Widianti tetap mempertahankan proses pembuatan batik serta peralatan yang digunakan secara tradisional tanpa terikat oleh waktu produksi. Namun demikian, terdapat beberapa penyesuaian yang dilakukan dalam usaha meningkatkan kenyamanan dalam bekerja. Hal ini terlihat pada peralatan yang dimodifikasi sehingga memenuhi standar kenyamanan fisik pekerjanya saat ini. Berbeda dengan peralatan yang digunakan, Widianti tetap mempertahankan proses pembuatan batik sebagai bagian dari wasiat yang diberikan kepadanya secara turun temurun. Resep dan proses pembuatan malam, rumus campuran warna, proses pencelupan serta proses kontrol tetap dilakukan hanya oleh Widianti sendiri dan tanpa adanya dokumentasi tertulis. Widianti juga menerapkan sistem kerja yang disiplin bagi setiap pekerjanya, sehingga 
setiap kain batik yang tidak lolos dari proses kontrolnya, maka kain tersebut akan dibakar meskipun telah melewati proses pembuatan batik yang panjang. Nilai-nilai yang diwariskan kepada Widianti, nantinya akan diturunkan hanya kepada keturunan darah keluarga Oey untuk menjaga kemurnian Batik Oey Soe Tjoen.

Namun, jika ternyata tidak terjadi regenerasi pada batik Oey Soe Tjoen maka Ia akan mengembalikan semua ilmu kepada Sang Maha Pemberi, seperti yang telah diwasiatkan pendahulunya kepadanya. Hal ini merupakan salah satu ancaman terbesar untuk kelangsungan batik Peranakan Oey Soe Tjoen. Selain dari hal tersebut, regenerasi pembatik tulis halus yang mampu memenuhi standar kerja batik Oey Soe Tjoen pun kian waktu kian melambat. Hal ini dikarenakan para pembatik terbaik yang dari dahulu bekerja sejak Oey Soe Tjoen generasi pertama, tidak mendidik dan melatih keturunannya menjadi pembatik tulis handal namun lebih ke pendidikan dan pekerjaan masa kini.

Proses pelestarian yang kini sedang dirintis oleh Widianti sebagai generasi terakhir adalah mendokumentasikan motif-motif batik Oey Soe Tjoen sejak generasi pertama, kedua, hingga kini. Motif-motif batik tersebut digambar ulang pada kain mori menggunakan malam panas sehingga diharapkan lebih tahan lama daripada penggambaran diatas kertas tipis. Selain dari pada itu, Widianti pun mulai menggelar beberapa pameran batik Oey Soe Tjoen untuk lebih memperkenalkan karya batiknya kepada kalangan umum dan kaum muda.

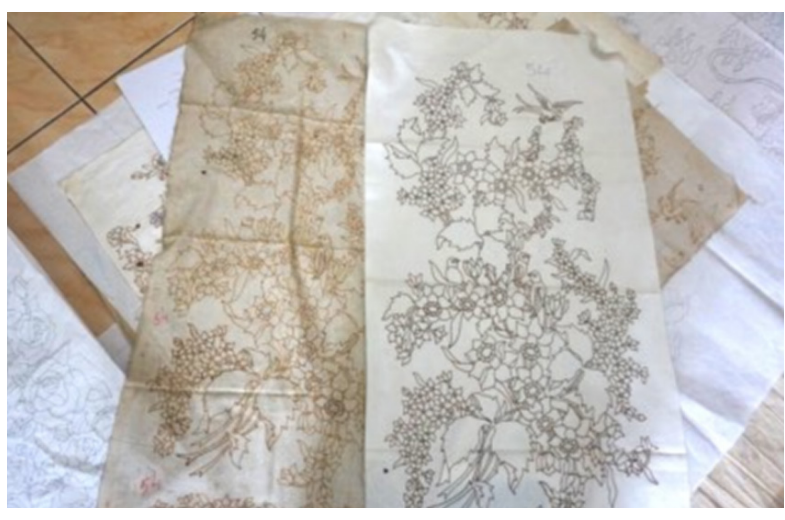

Gambar 2. Bagian dari usaha Widianti untuk merekonstruksi motif-motif legenda Batik Oey Soe Tjoen generasi pertama. (Sumber: Widyasari, 2017)

\section{Rumah Batik Oey Soe Tjoen}

Rumah batik Oey Soe Tjoen terletak di Kecamatan Kedungwuni Timur, sebelas kilometer sebelah selatan kota Pekalongan. Rumah batik ini terletak di kawasan pecinan yang terkenal akan batik Peranakannya sejak kurang lebih seratus tahun yang lalu. Keluarga Oey adalah salah satu keluarga pembatik Peranakan yang terkenal dari Kedungwuni. Hingga saat ini, masih bisa ditemukan di sepanjang jalan Raya Kedungwuni, empat buah rumah dengan tipologi yang sama, milik keluarga Oey. Rumah yang termasuk dengan kriteria Rumah Keluarga dan memiliki inner courtyard ini, dua diantaranya telah beralih fungsi sebagai tempat usaha yang lain. Sementara satu bangunan tidak dihuni namun masih terpelihara dengan baik dan keaslian ornamen khas Tionghoa masih terjaga. Sebuah bangunan lagi masih digunakan sebagai rumah batik Lim Ping Wie yang masih merupakan kerabat dekat Oey Soe Tjoen.

Rumah batik Oey Soe Tjoen berada tak jauh darirumah batik Lim Ping Wie. Dahulunya Oey Soe Tjoen memang meninggalkan rumah keluarga Oey untuk merintis batik tulis halus 


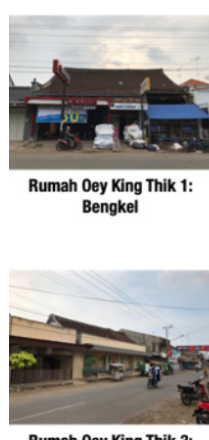

Rumah Oey King Thik 3 Kosong

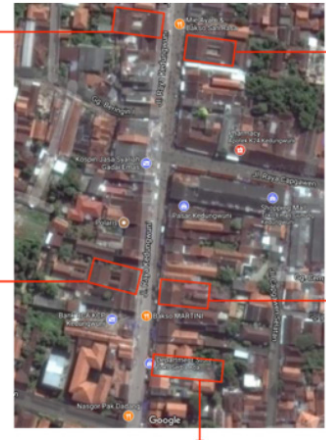

Rumah Batik Oey Soe Tjoen

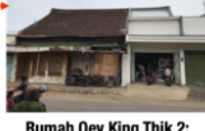

mah Oey King Thik 2 :
Toko Kelontong

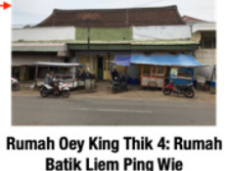

Batik Liem Ping Wie

Gambar 3. Situasi empat rumah keluarga Oey di Jalan Raya Kedungwuni

(Sumber: Widyasari, 2018)

secara mandiri bersama istrinya. Letak rumah batik Oey Soe Tjoen juga tidak terlalu jauh dengan Kampung Jrembeng Kembang, yang merupakan kampung pembatik di daerah Kedungwuni Timur. Para pembatik biasanya menggunakan transportasi berupa sepeda ataupun sepeda motor untuk mengakses rumah batik ini.

Berikut ini adalah gambar situasi jalan Raya Kedungwuni dengan lokasi empat rumah peninggalan keluarga Oey dan hubungannya dengan rumah batik Oey Soe Tjoen kini.

Bangunan rumah batik Oey Soe Tjoen terdiri dari tiga fungsi yang berbeda, yaitu sebagai hunian, toko kelontong, dan workshop batik. Dari tampak depan, bangunan ini hampir sama dengan ruko (rumah toko) berlantai satu biasa. Tidak ada ciri khas arsitektur Tionghoa yang tampak pada fasad bangunan. Namun, pada layout terlihat sistem grid dan pembagian zona area yang jelas. Bangunan yang menghadap ke arah barat ini menjadikan area depan yaitu showroom dan rumah tamu sebagai area publik dan semi publik. Fungsi hunian yang berada di tengah menjadi area privat dan fungsi workshop batik tulis sebagai semi publik.

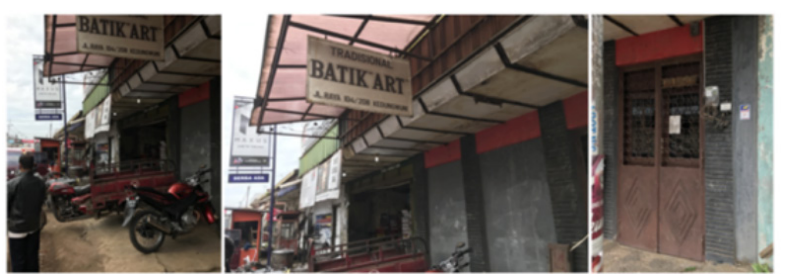

Gambar 4. Situasi rumah batik Oey Soe Tjoen (Sumber: Widyasari, 2018)

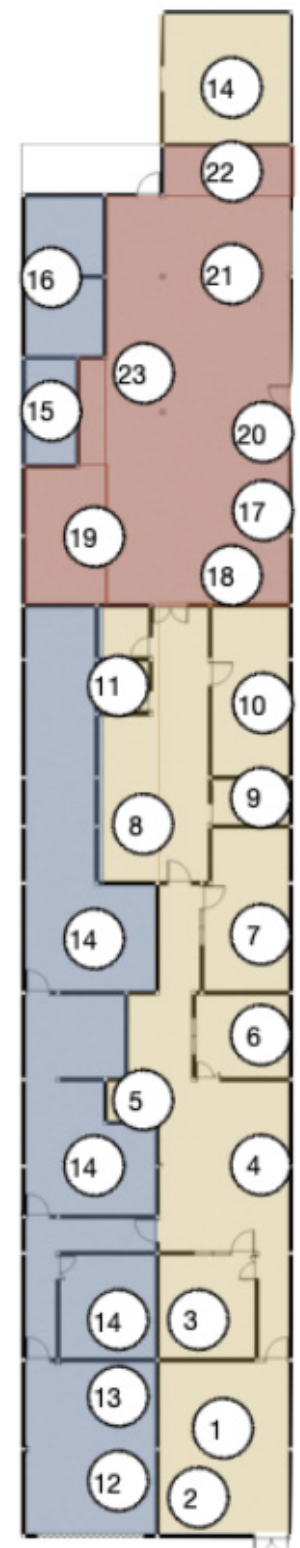

(1) Ruang Tamu

(2) Ruang Desain

(3) Kamar Tidur Oma

(4) Ruang Keluarga

(5) Toilet Tamu

6) Kamar Tidur Tamu

(7) Kamar Tidur Utama

(8) Dapur

9) Walking Closet

(10) Kamar Tidur Anak

(11) Kamar Mandi

(12) Area Display

(13) Area Kasir

(14) Gudang

(15) Kamar Mandi

(16) Hunian Pekerja Toko

(17) Workstation Lorod

(18) Ruang Penyimpanan

(19) Workstation Celup

(20) Meja Cuci

(21) Workstation Canting

(22) Ruang Kain

(23) Ruang Bersama

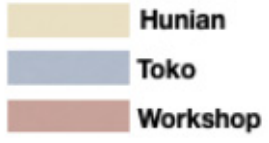

Gambar 5. Layout rumah Batik Oey Soe Tjoen yang terdiri dari tiga fungsi yaitu hunian, retail serta workshop batik tulis.

(Sumber: Widyasari, 2019)

Ruang tamu juga berfungsi sebagai ruang desain yaitu tempat Widianti membuat pola batik dan mengoreksinya sebelum masuk ke proses canting dan atau setelah kain selesai. 
Proses pembuatan motif biasanya dilakukan di malam hari, hal ini dikarenakan Widianti memerlukan konsentrasi dalam merancang. Berdasarkan pertimbangkan tersebut, juga pertimbangan cahaya matahari yang berlebih membuat bukaan dinding (jendela) ditiadakan pada proses renovasi rumah yang dilakukan pada tahun sebelumnya. Dengan demikian, hanya pintu dengan teralis besi menjadi akses masuk ke dalam bangunan dari fungsi hunian. Hal ini yang membuat sekilas fasad bangunan rumah batik Oey Soe Tjoen terkesan 'tertutup'.

Sistem grid terlihat pada denahbangunan. Ruang-ruang berbentuk persegi panjang yang efektif secara spasial juga melambangkan sisi duniawi. Meskipun tidak terdapat ruang altar ataupun ruang sembahyang, namun penghargaan terhadap nenek moyang tetap tampak pada ruang tamu dengan memanjang beberapa koleksi foto lama Oey Soe Tjoen dan keturunannya.

Area hunian berada ditengah bangunan yang terdiri dari tiga kamar tidur dan ruang keluarga yang menyatu dengan ruang makan. Area servis hunian bersebelahan dengan area servis toko kelontong (gudang penyimpanan). Area workshop batik dapat diakses melalui area servis retail maupun area hunian. Hal ini dikarenakan adanya pemisahan sirkulasi untuk menuju ke area belakang antara para pekerja dengan anggota keluarga atau pun tamu dari rumah batik Oey Soe Tjoen.

Gambar 6 merupakan bagan aksesbilitas ruang pada bangunan rumah batik Oey Soe Tjoen. Berdasarkan gambar bagan nomor 6 , maka dapat diketahui area yang bersifat publik yaitu area yang paling mudah diakses

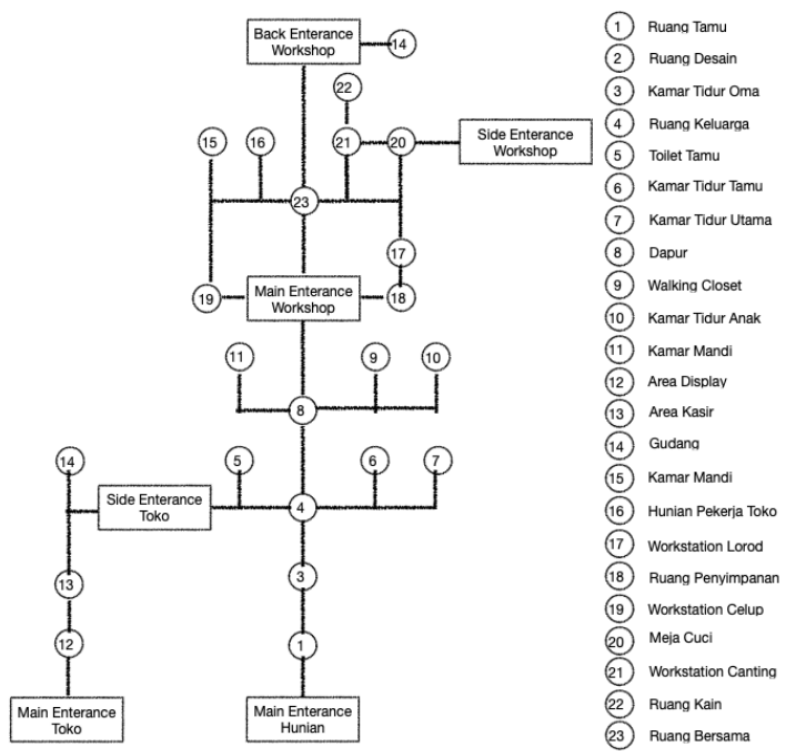

Gambar 6. Bagan aksesbilitas ruang rumah batik Oey Soe Tjoen

(Sumber: Widyasari, 2019)

atau tingkat aksesbilitas tinggi adalah ruang tamu pada hunian dan ruang display pada toko. Sementara itu, ruang keluarga dan dapur pada hunian, serta ruang bersama pada workshop merupakan ruang semi privat yang menghubungkan beberapa ruang privat. Sedangkan ruang penyimpanan kain pada workshop batik, merupakan ruang dengan tingkat aksesbilitas paling rendah karena terletak di area paling belakang bangunan.

\section{Workshop Batik Oey Soe Tjoen}

Workshop batik Oey Soe Tjoen terletak di belakang bangunan, berbatasan langsung dengan dapur. Workshop batik ini mampu menampung seluruh proses pembuatan batik dari awal hingga akhir. Workshop batik Oey Soe Tjoen merupakan bangunan dengan dinding campuran antara plesteran batu bata dengan dinding bambu. Lantai masih berupa plesteran semen tanpa keramik dan struktur atap dengan ketinggian yang cukup tinggi 


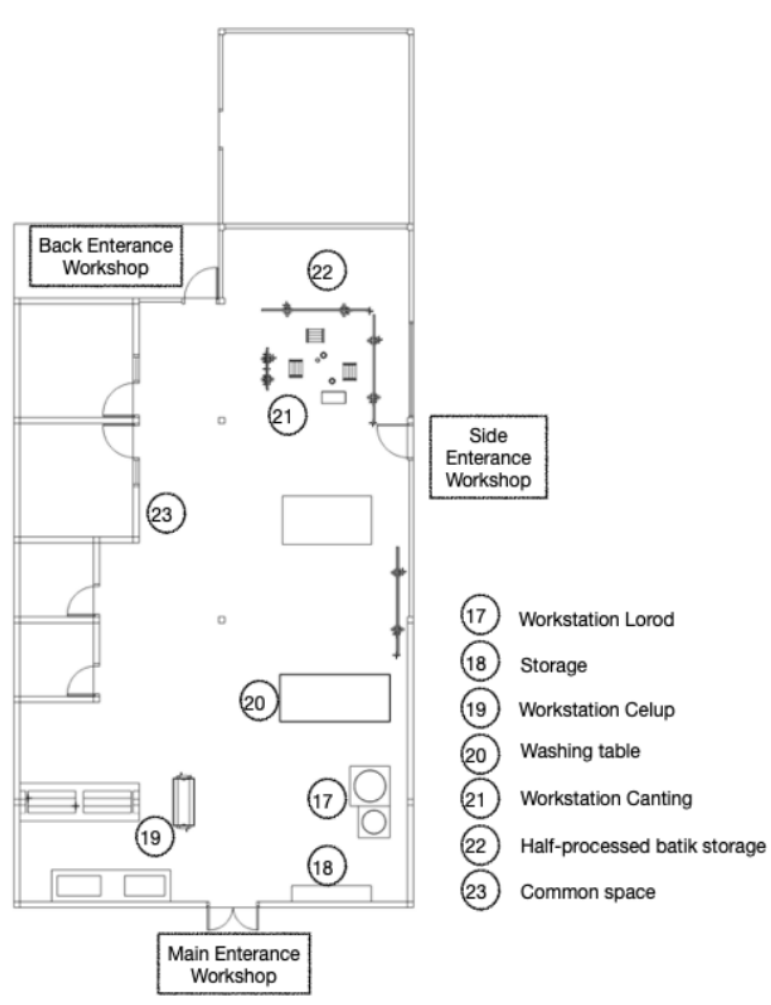

Gambar 7. Layout workshop batik Oey Soe Tjoen (Sumber: Widyasari, 2019)

yang terbuat dari struktur kayu dan bambu serta penutup atap dari seng. Workshop ini berbentuk ruang tertutup tanpa adanya sekat dengan area kerja yang tersusun mengikuti alur produksi.

Workshop batik Oey Soe Tjoen memiliki susunan sebagai berikut, berurutan dari ruang yang berbatasan langsung dengan fungsi hunian:

- Ruang celup, nglorod serta penyimpanan obat pewarna kain.

- Ruang pencucian kain dari tepung dan ruang pengeringan dalam.

- Ruang canting dan ruang penyimpanan kain yang belum selesai.

- Ruang pengeringan yang terletak di luar bangunan.

Bagian belakang dari bangunan rumah batik Oey Soe Tjoen ini didominasi oleh

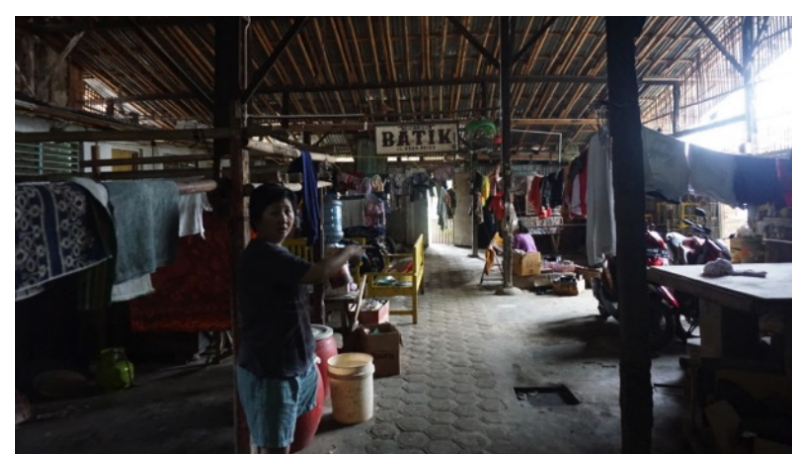

Gambar 8. Suasana workshop batik tulis Oey Soe Tjoen

(Sumber: Widyasari, 2017)

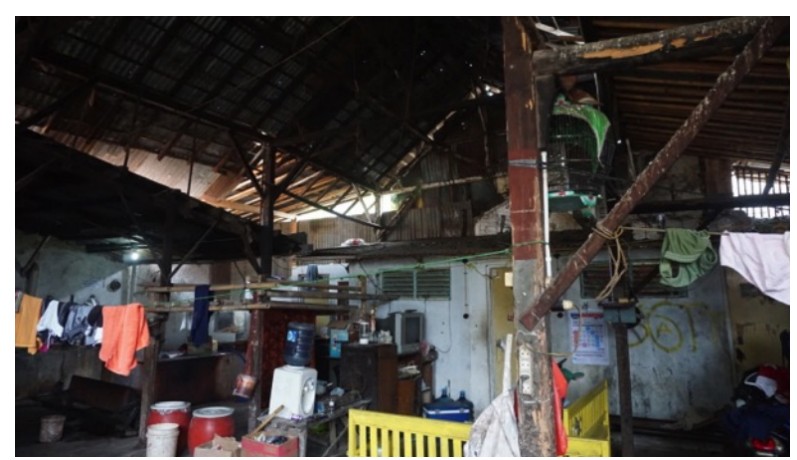

Gambar 9. Struktur atap workshop batik Oey Soe Tjoen yang terbuat dari kayu dan bambu (Sumber: Widyasari, 2017)

fungsinya sebagai workshop batik pada pagi hingga sore hari. Pada malam hari, area ini lebih banyak digunakan sebagai hunian dan servis bagi para pekerja toko kelontong. dengan demikian, terdapat ruang dan peralatan yang digunakan secara bergantian baik untuk kepentingan workshop batik maupun untuk kepentingan para pekerja toko kelontong, contohnya kamar mandi, bak cuci air, dan kompor.

Tata letak workstation dalam workshop sudah sesuai dengan alur produksi batik tulis ini, meskipun workstation canting terletak di area yang paling belakang. Beberapa modifikasi terlihat pada peralatan yang digunakan dalam proses pencucian kain dan proses pewarnaan. Hal ini adalah hasil dari pertimbangan kenyamanan para pekerja 
Tabel 1. Tahapan produksi I batik Oey Soe Tjoen, ruang-ruang yang digunakan serta diagram aksesbilitas

\begin{tabular}{|c|c|c|c|}
\hline No. & $\begin{array}{c}\text { Tahapan } \\
\text { Membatik }\end{array}$ & Ruang yg dibutuhkan & Aksesbilitas \\
\hline 1 & Membuat Desain & Ruang Desain & 7) \\
\hline 2 & Nglowongi & Workstation Canting & \\
\hline 3 & Ngiseni & $\begin{array}{l}\text { Workstation Canting/ } \\
\text { Rumah Pembatik }\end{array}$ & \\
\hline 4 & Mopok & Workstation Canting & \\
\hline 5 & Nerusi & $\begin{array}{l}\text { Workstation Canting/ } \\
\text { Rumah Pembatik }\end{array}$ & \\
\hline 6 & Ngelir & $\begin{array}{l}\text { Meja Cuci }+ \\
\text { Workstation Celup }\end{array}$ & $\begin{array}{l}\text { Workstation Lorod } \\
\text { Ruang Penvimpanan }\end{array}$ \\
\hline 7 & Njareti & $\begin{array}{l}\text { Workstation Canting/ } \\
\text { Rumah Pembatik }\end{array}$ & $\begin{array}{l}\text { Workstation Celup } \\
\text { Meja Cuci }\end{array}$ \\
\hline 8 & Mopok- Ngelir & $\begin{array}{l}\text { Workstation Canting - } \\
\text { Celup }\end{array}$ & Workstation Canting \\
\hline 9 & $\begin{array}{c}\text { Nglorod, Ngerok, } \\
\text { Mencuci, Jemur, } \\
\text { Kanji+Tarik+Kem- } \\
\text { plong }\end{array}$ & $\begin{array}{l}\text { Workstation Lorod, } \\
\text { Canting, Meja Cuci, } \\
\text { Halaman }\end{array}$ & $\begin{array}{l}\text { Ruang Kain } \\
\text { Ruang Bersama }\end{array}$ \\
\hline
\end{tabular}

Tabel 2. Tahapan produksi II batik Oey Soe Tjoen, ruang-ruang yang digunakan serta diagram aksesbilitas

\begin{tabular}{|c|c|c|c|c|}
\hline No. & $\begin{array}{c}\text { Tahapan } \\
\text { Membatik }\end{array}$ & Ruang yg dibutuhkan & Kode Ruang & Aksesbilitas \\
\hline 1 & Nandesi Klowongan & Workstation Canting & & \\
\hline 2 & Mbironi & $\begin{array}{l}\text { Workstation Canting/ } \\
\text { Rumah Pembatik }\end{array}$ & & \\
\hline 3 & Nerusi & $\begin{array}{l}\text { Workstation Canting/ } \\
\text { Rumah Pembatik }\end{array}$ & & \\
\hline 4 & Lepan & Workstation Canting & & Ruang Penyimpanan \\
\hline 5 & Ngelir & $\begin{array}{l}\text { Meja Cuci }+ \\
\text { Workstation Celup }\end{array}$ & & $\begin{array}{l}\text { Meja Cuci } \\
\text { Workstation Canting }\end{array}$ \\
\hline 6 & Ngelir & $\begin{array}{l}\text { Meja Cuci + } \\
\text { Workstation Celup }\end{array}$ & & $\begin{array}{l}\text { Ruang Kain } \\
\text { Ruang Bersama }\end{array}$ \\
\hline
\end{tabular}


Tabel 3. Tahapan produksi III batik Oey Soe Tjoen, ruang-ruang yang digunakan serta diagram aksesbilitas

\begin{tabular}{|c|c|c|c|c|}
\hline No. & Tahapan Membatik & $\begin{array}{c}\text { Ruang yg } \\
\text { dibutuhkan }\end{array}$ & Kode Ruang & Aksesbilitas \\
\hline 1 & $\begin{array}{c}\text { Latar Polos - Nandesi } \\
\text { Klowongan, Mopok, } \\
\text { Ngelir } \\
\end{array}$ & $\begin{array}{c}\text { Workstation } \\
\text { Canting, } \\
\text { Workstation Celup }\end{array}$ & & \multirow{5}{*}{$\begin{array}{l}\text { (17) Workstation Lorod } \\
\text { (18) Ruang Penyimpanar } \\
\text { (19) Workstation Celup } \\
\text { (20) Meja Cuci } \\
\text { (21) Workstation Canting } \\
\text { (22) Ruang Kain } \\
\text { (23) Ruang Bersama }\end{array}$} \\
\hline 2 & $\begin{array}{c}\text { Latar Tanahan - } \\
\text { Ngeseni latar, Nerusi, } \\
\text { Ngelir }\end{array}$ & $\begin{array}{c}\text { Workstation } \\
\text { Canting/Rumah } \\
\text { Pembatik, } \\
\text { Workstation Celup }\end{array}$ & & \\
\hline 3 & Penirisan & Workstation Celup & & \\
\hline 4 & $\begin{array}{c}\text { Nglorod, Ngerok, } \\
\text { Mencuci, Jemur, } \\
\text { Kanji+Tarik+Kemplong } \\
\end{array}$ & $\begin{array}{c}\text { Workstation Lorod, } \\
\text { Canting, Meja } \\
\text { Cuci, Halaman } \\
\end{array}$ & & \\
\hline 5 & $\begin{array}{l}\text { Pengepresan dan } \\
\text { pengemasan kain } \\
\text { batik }\end{array}$ & $\begin{array}{l}\text { Ruang Tamu dan } \\
\text { Ruang Desain }\end{array}$ & & \\
\hline
\end{tabular}

dalam melakukan prosesnya. Setiap area kerja atau workstation pada workshop ini tidak memiliki pembatas ruang atau sekat secara fisik. Batasan area hanya bersifat perbedaan ketinggian lantai atau susunan perletakan alat yang membentuk ruang kerja tersendiri. Hal ini menyebakan sirkulasi free flow sehingga pembatik dapat bergerak bebas ke masingmasing area kerja pada saat proses produksi.

Lantai yang dilapisi oleh plester semen tanpa keramik serta dinding yang terbuat dari kombinasi batu bata dengan dinding kayu, seng, dan bambu, ketinggian atap yang cukup tinggi dan tanpa plafon sehingga memperlihatkan struktur atap yang terbuat dari kayu, seng, dan bambu, membuat bangunan workshop ini terkesan 'jujur' pada struktur. Penggunaan material kayu, bambu, dan seng yang bersifat ringan ini memperkuat pendapat Antariksa (2016) bahwa arsitektur Tionghoa dibangun tidak dengan bahan permanen, mungkin ada hubungannya dengan negasi terhadap segala bentuk yang bersifat fana.

Bukaan dinding berupa jendela besar, lubang angin dan pintu menuju halaman belakang mampu memaksimalkan pencahayaan dan pengkondisian udara alami. Oleh sebab itu, pekerjaan canting yang dilakukan dari pagi hingga sore hari menggunakan cahaya matahari sebagai penerangannya.

\section{Proses Batik pada Workshop Oey Soe Tjoen}

Berdasarkan tahapan proses membatik dalam rumah batik Oey Soe Tjoen yang telah dipaparkan sebelumnya oleh Liong (2004), maka dapat digambarkan hubungan antara proses pembuatan batik, ruang yang digunakan, serta aksesbilitas dari setiap tahapan membatik dari tahap I, II, dan III.

Berdasarkan tabel beberapa tahapan membatik diatas, maka tampak bahwa workstation canting dengan kode ruang (21) 
merupakan ruang yang memiliki peranan penting dalam tahapan membatik khususnya pada rumah batik Oey Soe Tjoen. Hal ini dikarenakan proses memproduksi batik dengan canting merupakan proses yang sering dan berulang tergantung dari desain dan motif yang terdapat pada kain. Oleh sebab itu, ruang workstation canting juga memiliki frekuensi tinggi dalam hal aksesbilitas.

\section{Workstation Canting}

Workstation canting terletak dibagian belakang workshop batik Oey Soe Tjoen. Terletak di sudut ruang dengan dua pintu yang memudahkan sirkulasi baik pengguna ruang maupun sirkulasi udara. Terdapat bukaan dinding berupa jendela dari bambu dengan dimensi yang cukup luas, sehingga memaksimalkan pencahayaan alami dan sirkulasi udara.

Tidak ada batasan fisik yang jelas pada workstation canting. Ruangan ini hanya ditandai oleh kolom struktur kecil dan susunan gawangan yang membentuk ruang tertentu. Gawangan yang bersifat dinamis dapat merubah batasan ruang dengan mudah. Jumlah para pekerja canting, jenis pekerjaannya sertajenis, danjumlah gawangan yang digunakan menjadi faktor penentu terbentuknya ruang dalam workstation canting ini. Susunan gawangan dan tempat duduk pembatik dengan tungku sebagai pusatnya membentuk pola yang memusat (Widyasari, Sriwarno, \& Adhitama, 2018). Berikut beberapa perbandingan ruang yang terbentuk dalam area workstation canting.

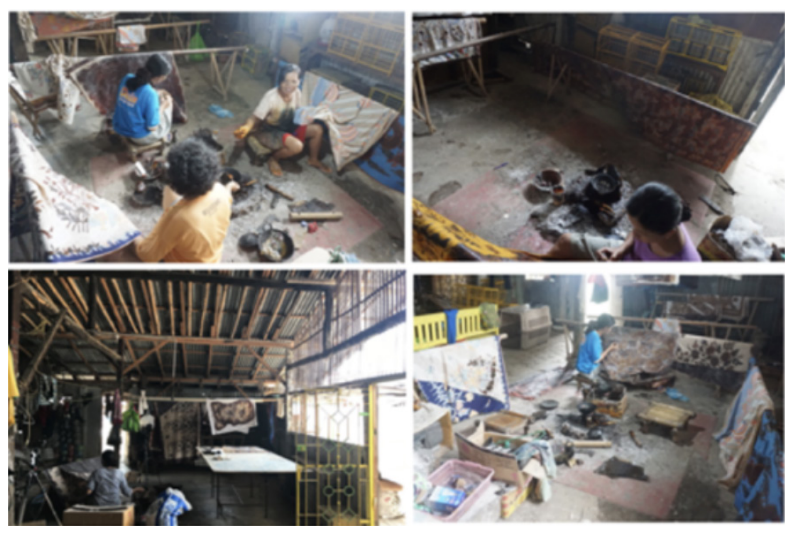

Gambar 10. Suasana workstation canting dengan berbagai layout tempat duduk dan gawangan pembatik

(Sumber: Widyasari, 2019)

Dalam workstation canting terdapat beberapa gawangan yang terbuat dari bambu dan dari pipa besi dengan ukuran yang berbeda-beda pula. Gawangan yang biasa digunakan dalam proses canting khususnya pekerjaan klowongan dengan canting kecil adalah gawangan yang terbuat dari bambu. Tata letak gawangan dalam workstation canting dapat berubah sesuai dengan kebutuhan proses batik yang sedang berlangsung. Biasanya dalam workstation canting terdiri dari satu hingga empat orang pembatik yang duduk mengelilingi satu atau dua buah tungku yang berisi malam panas. Tatanan gawangan dan dingklik atau kursi pendek tanpa sandaran bagi para pembatik membentuk suatu pola tertentu dengan tungku sebagai pusatnya.

Dari pola tertentu yang bersifat sirkular ini, dapat dilihat lebih dalam tentang hubungan yang terjadi antara pembatik dengan peralatan yang digunakan dalam proses canting. Para pembatik yang umumnya bekerja dengan menggunakan tangan kanan, mengambil malam dari tungku dengan menggunakan canting, meniup malam panas 

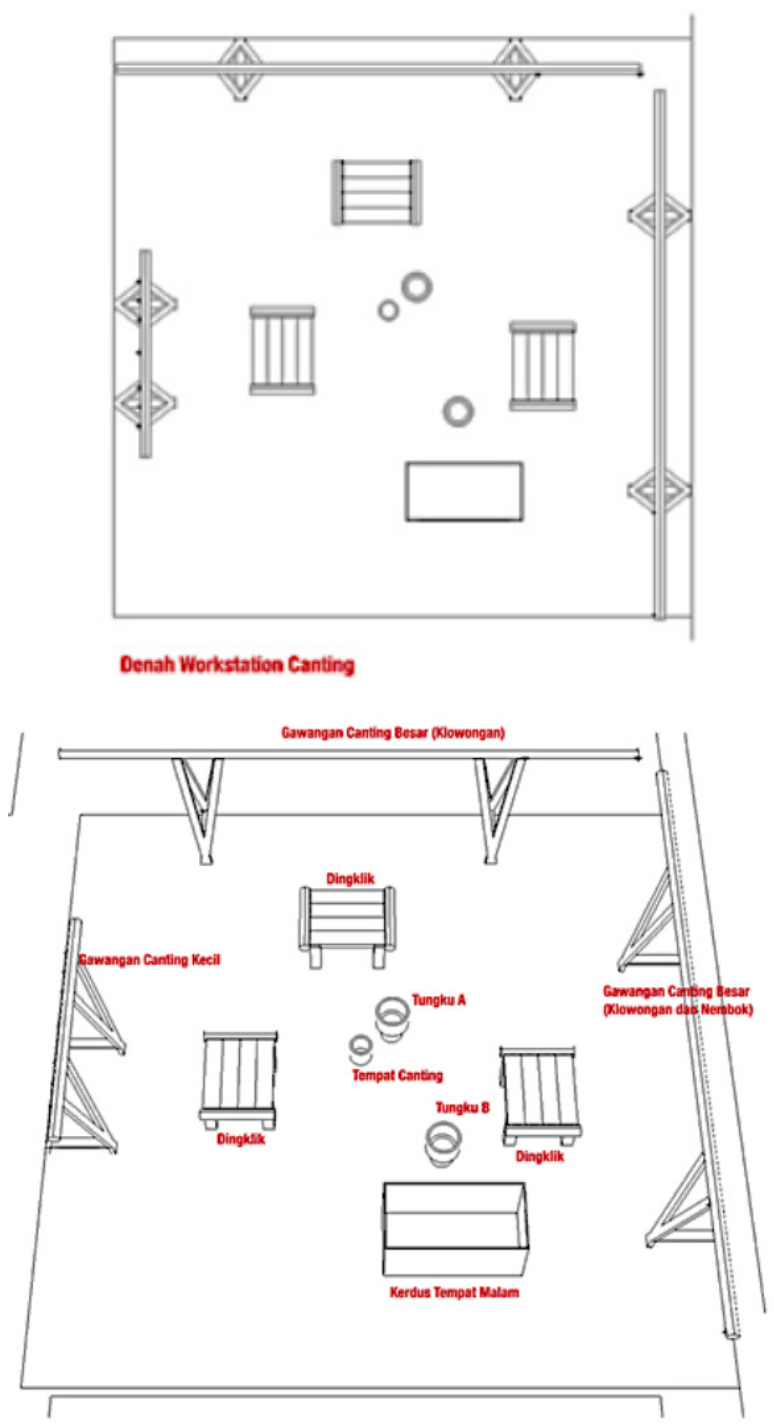

Gambar 11. Layout workstation canting dengan tiga buah gawangan yang mengelilingi dua tungku (Sumber: Widyasari, 2019)

dan kemudian menorehkannya keatas kain yang disampirkan pada gawangan. Proses ini kemudian berulang sehingga menjadi sebuah siklus yang dapat dijadikan dasar pengamatan perilaku pembatik dalam hubungannya dengan alat dan ruang pada proses canting.

Dalam proses membatik dengan canting terjadi interaksi antar para pembatik. Selama proses canting, para pembatik biasanya saling bercerita dan bercanda mengenai kehidupan sehari-hari ataupun mengenai suatu bahasan tertentu dalam lingkup kekeluargaan. Masa bekerja yang cukup lama, beberapa pembatik bahkan hingga puluhan tahun, membuat keterikatan antara satu pembatik dengan yang lainnya sangat kuat. Widianti sebagai pemilik batik Oey Soe Tjoen memang masih menggunakan pembatik yang berkerja sejak generasi kedua bahkan generasi pertama. Keterikatan dan rasa kekeluargaan antara pemilik usaha dengan para pekerja ini memang diturunkan dan dilestarikan sejak Oey Soe Tjoen generasi pertama hingga kini.

Pekerjaan canting yang biasanya dilakukan di workshop adalah jenis pekerjaan klowongan ataupun koreksi pekerjaan canting sebelum masuk ke proses pewarnaan. Sedangkan untuk proses canting nyecek atau isen-isen biasanya dilakukan dirumah pembatik masing-masing dengan menggunakan canting nol dan tanpa menggunakan gawangan. Namun demikian, beberapa pembatik lebih sering mengerjakan pekerjaannya di workshop sesuai dengan jam kerja mereka yaitu dari jam delapan pagi hingga jam empat sore.

Sudah menjadi sebuah tradisi sejak Oey Soe Tjoen generasi pertama untuk membuat sendiri malam yang akan digunakan dalam proses canting. Resep pembuatan ini hanya diwariskan pada keturunan langsung dari keluarga Oey dan tidak dibagi dengan siapa pun karena termasuk dalam rahasia dagang. Malam dengan kualitas terbaik digunakan untuk pekerjaan detail yang menggunakan canting kecil. Setelah malam melalui proses nglorod, maka malam dengan kualitas kedua digunakan pada pekerjaan klowongan dengan menggunakan canting sedang. Malam dengan kualitas ketiga digunakan untuk 
proses nembok. Hal ini berkaitan dengan jenis pekerjaan dan tungku yang digunakan. Setiap tungku berisi dengan jenis malam yang berbeda. Sehingga jika terdapat dua jenis pekerjaan maka terdapat dua buah tungku, demikian seterusnya

\section{PENUTUP}

Pada usaha batik tulis tradisional Oey Soe Tjoen, proses membatik dengan canting adalah sebuah proses yang dangat penting. Hal ini dikarenakan rumah batik Oey Soe Tjoen hanya memproduksi batik tulis halus dengan sebagaian besar prosesnya menggunakan canting nol dan metode pewarnaannya yang menggunakan teknik celup. Proses membatik dengan canting berulang-ulang dilakukan sesuai dengan desain yang diinginkan diawal proses produksi batik. Signifikansi proses membatik dengan canting ini turut menjadikan ruang yang mewadahi prosesnya, yaitu workstation canting, menjadi sebuah ruang yang penting dalam ruang usaha batik secara keseluruhan atau workshop batik.

Pada workshop batik tulis Oey Soe Tjoen terdapat keunikan layout yang menempatkan workstation canting pada area paling belakang sebuah workshop. Padaumumnya sebuah ruang yang sering digunakan dan memiliki peran penting akan terletak pada area yang mudah diakses, namun workstation canting pada workshop ini tidak demikian. Penempatan letak workstation canting dalam workshop batik tulis ini adalah lebih berdasarkan pertimbangan pencahayaan alami dan sirkulasi udara yang maksimal. Hal ini dikarenakan pada area

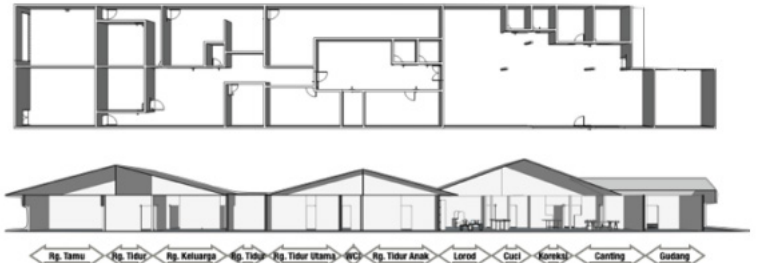

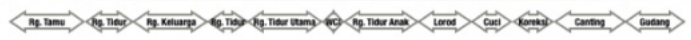

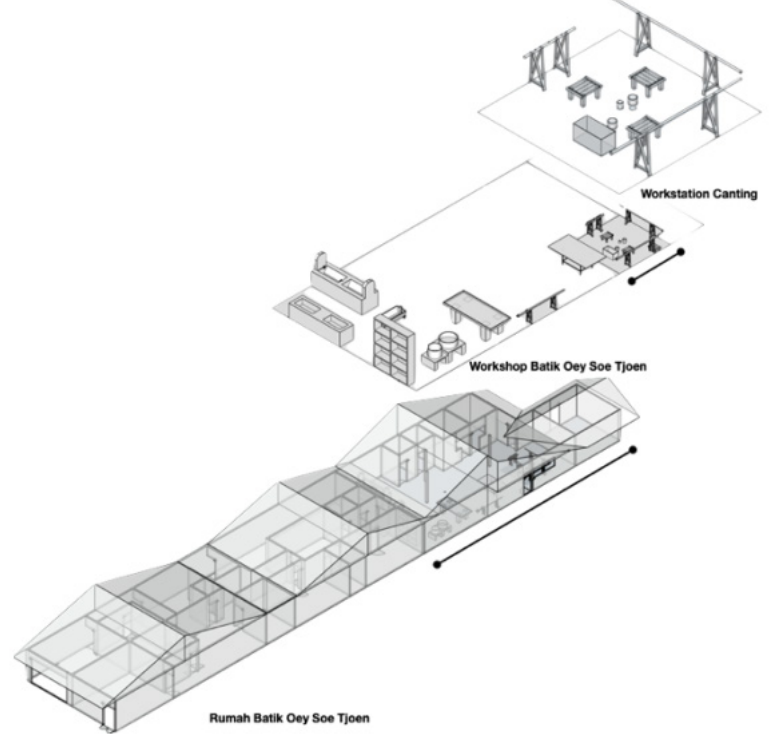

Gambar 12. Layout bangunan rumah batik Oey Soe Tjoen, workshop dan workstation canting

(Sumber: Widyasari, 2019)

tersebut terdapat sebuah jendela besar dan dua buah pintu sebagai akses ke luar bangunan menuju area jemur dan area terbuka bagian belakang.

Proses membatik dengan canting adalah proses dengan tingkat konsumsi waktu yang tinggi dengan penggunaan peralatan seperti tungku dan malam, oleh sebab itu faktor pencahayaan dan sirkulasi udara sangat penting untuk kesehatan dan keselamatan para pembatik, sehingga dapat meningkatkan produktivitas kerja. 


\section{Daftar Pustaka}

Antariksa. (2016). Teori dan Metode Pelestarian Kawasan Pecinan (5th ed.). Yogyakarta: Cahaya Atma Pustaka.

Hasanudin. (2001). Batik pesisiran: melacak pengaruh etos dagang santri pada ragam hias batik. Kiblat Buku Utama.

Hastuti, D. L. (2017). Desain Interior Toko Sebagai Pembentuk Suasana Rumah Saudagar di Kampung Batik Laweyan. Panggung, 26(4). https://doi.org/10.26742/ panggung.v26i4.205

Kwa, D. (2018). Ragam Pakaian Kaum Peranakan. In L. Wibisono \& R. Tjahyadi (Eds.), Peranakan Tionghoa Indonesia; Sebuah Perjalanan Budaya (3rd ed., pp. 259284). Jakarta: Komunitas Lintas Budaya Indonesia/Indonesian Cross-Cultural Community dan Intisari.

Liong, W. K. H. (2014). Oey Soe Tjoen: Duta Batik Peranakan. Kementrian Pariwisata Republik Indonesia dan Red \& White Publishing.

Sriwardani, N., \& Savitri. (2019). Rumah Adat Kampung Pulo Cangkuang Kabupaten Garut sebagai Konsep Hunian Masa Kini. Panggung, 29(3), 284-298.

Widyasari, R. K., Sachari, A., Sriwarno, A. B., \& Adhitama, G. P. (2020). The Effects of Worker's Behavior Changes on Batik Equipment in Traditional Batik Process of Oey Soe Tjoen. Arts and Design Studies, 80, 1-8. https://doi.org/10.7176/ads/8001

Widyasari, R. K., Sriwarno, A. B., \& Adhitama, G. P. (2018). The Analysis of Centralized Layout on Traditional Batik Tulis Workshop in Central Java. In The Asian Conference on Arts \& Humanities 2018 Official Conference Proceedings. Retrieved from http://papers.iafor.org/ wp-content/uploads/papers/acah2018/ ACAH2018_40314.pdf 